\title{
DECONSTRUCTING LANGUAGE LEARNERS' FEELINGS OF INFERIORITY THROUGH TELETANDEM
}

\author{
Desconstruindo a sensação de inferioridade de aprendizes de \\ línguas por meio do Teletandem
}

Paula A. ZULAICA-GÓMEZ1

\begin{abstract}
Teletandem is based on principles of reciprocity, equality, collaboration, and autonomy between two participants who are eager to learn their target language and share their knowledge of the one in which they are proficient at the same time. While this is true, each party comes to the experience with their own context, perception, and attitudes towards their target language, and thus, their circumstances are unequal, particularly those pertaining to their motivation for enrolling in a foreign language class. In the case of Mexican learners of English as a foreign language, several sociocultural factors, resulting from the country's colonial history affect their motivation and attitude towards English. This article focuses on a) how perceptions and attitudes towards English affect the willingness of Mexican learners to participate in teletandem sessions by self-imposing a lower station within a preconceived social hierarchy, and b) how teletandem can break through these preconceived notions and change the way they perceive themselves and their partners. Results of post-session evaluations reveal how after participating in teletandem and reflecting on the experience, they report increased motivation and confidence in their target language skills.
\end{abstract}

Keywords | Teletandem. Telecollaboration. Student identity. Autonomy. Student inferiority complex.
Resumo | O Teletandem baseia-se em princípios de reciprocidade, igualdade, colaboração e autonomia entre os dois participantes, ansiosos por aprender a língua-alvo e partilhar o seu conhecimento daquele idioma em que são proficientes, ao mesmo tempo. Embora isso seja verdade, cada parte chega à experiência com o seu próprio contexto, percepção e atitudes em relação à sua língua-alvo e, assim, as suas circunstâncias são desiguais, particularmente aquelas relacionadas com a sua motivação para se matricularem numa aula de língua estrangeira. No caso dos alunos mexicanos de inglês como língua estrangeira, vários fatores socioculturais, resultantes da história colonial do país, afetam sua motivação e atitude em relação ao inglês. Este artigo enfoca a) como as percepções e atitudes em relação ao inglês afetam a disposição dos aprendizes mexicanos de participar de sessões de teletandem, autoimpondo uma posição inferior dentro de uma hierarquia social preconcebida e b) como o teletandem pode romper essas noções preconcebidas e mudar a maneira como eles percebem a si e a seus parceiros. Os resultados das avaliações pós-sessão revelam como depois de participar do teletandem e refletir sobre a experiência, eles relatam maior motivação e confiança em suas habilidades no idioma alvo.

Palavras-chave | Teletandem. Telecolaboração. Identidade dos alunos. Autonomia. Complexo de inferioridade dos alunos.

1 Gomez. ITESO. E-mail: zulaica@iteso.mx. ORCID ID: https://orcid.org/0000-0003-4057-6090 
- | Deconstructing language learners' feelings of inferiority through teletandem

\section{Introduction}

Reciprocity, equality, collaboration, and autonomy are the foundational characteristics of tandem language learning and its technology-mediated variation, teletandem. Literature in the field has focused on how these foundational characteristics work in the interaction between participants (BRINCKWIRTH, 2012; CAPELLINI, 2016; CONSOLO \& FURTOSO, 2015; TELLES, 2015a, 2015b; VASSALLO, 2010). Since tandem interactions feature individuals who take turns both playing the role of learner (of their target language) and of expert (of their native language or one in which they are proficient) the concept of identity has risen to be one of critical focus. Due to the nature of tandem interactions and the link between language and identity, the emergence of identity studies regarding tandem learning is an obvious one. A logical result of the juxtaposition of the concepts of identity and reciprocity/equality is the tension between participants' national and personal identities confronted with the concept of equality of circumstances and reciprocal participation. How can equality of circumstances and reciprocity of effort exist, when the exercise of tandem and teletandem learning brings about two participants who share, not only their language of expertise (native or not), but themselves and their sense of identity? More so, what would happen when a natural occurrence of such interaction is the confrontation of preconceived notions about the target language and its speakers with real speakers of the said language?

The Literature Review \& Theoretical Framework of this paper will recount some of the most important works on this topic. Still, there is a gap in the literature regarding selfimposed power dynamics and their effects in the willingness of participants to engage in teletandem, as well as the role that teletandem can play in breaking through the reluctance to participate and their confidence in their target language skills and the reorganization of their sense of self.

The present article closes this gap by analyzing how teletandem can break through the dichotomy of Mexican attitudes towards foreign language and culture, leading to increased motivation and autonomy among Mexican university-level English learners. The observed students participated in teletandem sessions with collaborating institutions in the United States of America and, to a lesser degree, Canada from 2012 to 2018.

The thesis of this paper is then, that a natural reluctance to participate in teletandem arises from students' self-imposed feelings of inferiority, though teletandem can break through the said feelings, increasing confidence and motivation, which in turn change their perception of the English language and their attitude towards learning it. This change, 
then, generates linguistic and learning awareness, hence encouraging them to become autonomous learners.

\section{Background}

The teletandem program at ITESO, The Jesuit University of Guadalajara, Mexico (where the observed participants for this article are enrolled) started with sporadic attempts by a few of the English language teachers in their classrooms, using laptops and relying on WIFI connection in the 2010-2011 academic year, to poor results stemming from connectivity issues. In 2012, ITESO joined the official teletandem and telecollaboration program instituted by AUSJAL-AJCU (the Jesuit Universities Associations of Latin America and the United States, respectively), known as Programa Inmersión Dual Virtual AUSJALAJCU. From 2012 to the present, ITESO has had a consistent and structured teletandem and telecollaboration program; it started with in-class English-Spanish linguistic exchanges, and it has grown to include curricular courses telecollaboration projects in the vein of SUNY's Collaborative Online International Learning (COIL) model (SUNY COIL CENTER, 2013). Furthermore, ITESO has extended its teletandem efforts to include collaborations with non-Jesuit institutions, and it is currently working on starting French-Spanish linguistic exchanges with Quebec, Canada.

Teletandem is a model of mutual language acquisition between two proficient speakers of different languages who, through collaboration, play the roles of teacher and learner simultaneously. Tandem learning, from which teletandem emerges, has its origin in Joseph Lancaster's "mutual system", developed at the beginning of the 19th century. This method was then used in the 60s between French and German schools. Michael Friederich and Jurgen Wolff coined the term tandem learning in the 70s, using the metaphor of the tandem bicycle, where both riders' effort is required to advance. Later in 1992, Helmut Brammerts and David Little introduced a new age in tandem learning, characterized by the introduction of technology, first with the asynchronous sessions via email and later, in the new millennium, with real-time exchanges taking advantage of online video conferencing platforms, known by different terms and with variations to their models: etandem, telecollaboration, teletandem. (WORLD HERITAGE ENCYCLOPAEDIA). The tandem sessions model in which ITESO participates follows the model of Teletandem Brasil, of Universidade Estadual Paulista (UNESP), created by Dr. João Telles, who coined the term teletandem (TELETANDEM BRASIL: FOREIGN LANGUAGES FOR ALL, 2015). Teletandem sessions at ITESO are 50 minutes long, with 25 minutes devoted to one language and the other 25 minutes to the other, with the emphasis in not mixing the languages. 
- | Deconstructing language learners' feelings of inferiority through teletandem

As stated before, tandem learning is characterized by the principles of reciprocity, equality, collaboration, and autonomy, which create a safe environment where both participants come eager to learn from a proficient speaker who is not a teacher. Participants seem at ease in a space free of criticism, acknowledging that both are learners and prone to mistakes. While this is true, it is essential to keep in mind that each party comes to the table with their own context, perception, and attitude towards their target language, and thus, their specific circumstances are not the same; particularly those pertaining to their motivation for enrolling in a foreign language class. The reasoning behind this statement is that the motivation to enroll in a foreign language class may follow a practical reason, such as it being part of the curriculum, a graduation requirement or both; or a less practical one, such as to diversify one's education or a personal preference for the language and culture. To understand the background of the students participating in ITESO's teletandem program we provide the following profile:

\begin{tabular}{|c|c|}
\hline \multirow{5}{*}{$\begin{array}{l}\text { Mexican Teletandem } \\
\text { Participants' Profile }\end{array}$} & Mexican private university students. \\
\hline & 18-22 years old. \\
\hline & Contact with English from an early age. \\
\hline & $\begin{array}{l}\text { Enrolled in an English language class within the English } \\
\text { Certificate Program, an integrated four-skills program of } \\
\text { eight levels, designed to take English learners to a B2 level of } \\
\text { proficiency, as stated by the Common European Framework } \\
\text { of Reference for Languages (CEFRL). }\end{array}$ \\
\hline & $\begin{array}{l}\text { The Institutional English Requirement at ITESO states that a } \\
\text { student must certify a B2 CEFRL level. Students have a choice } \\
\text { to complete the requirement: either by an international } \\
\text { proficiency examination, such as TOEFL, IELTS or FCE; or } \\
\text { by completing the program's eight levels of English. The } \\
\text { objective of the Institutional English Requirement is providing } \\
\text { students with a significant tool for academic research and } \\
\text { access to international exchange programs. } \\
\text { The Institutional English Requirement is also a prerequisite for } \\
\text { students to obtain their titulo profesional. }\end{array}$ \\
\hline
\end{tabular}


Since the 1920s, the English language has been obligatory in the secondary school curriculum in Mexico, and since 2009 it has been obligatory at a familiarization level starting in preschool and as a formal language program beginning in 3rd grade of elementary school, as ruled by the Secretaría de Educación Pública, the government department in charge of education in Mexico. However, it is important to mention that since ITESO is a private university, the majority of its students come from private schooling, where the prevalence of English in primary education predated the 2009 National English Program reform (PNIEB) (SECRETARÍA DE EDUCACIÓN PÚBLICA, 2009).

It is also important to note that, as opposed to the United States higher education model (and other international higher education ones), Mexican higher education makes a distinction between graduating from an undergraduate degree, understood as completing all the coursework required, and the titulo profesional, a government-sanctioned license to practice professionally. A Mexican student who completes all of his or her coursework is considered a pasante until they fulfill all the conditions needed by both their educational institution and the Secretaría de Educación Pública. Failing to do so means that they will earn significantly less when entering the workforce, have their employment options considerably reduced, or both. (MAGAZINER; MONROY, 2016).

\section{Literature Review \& Theoretical Framework}

As stated in the introduction, the research on identity and social dynamics in tandem/teletandem learning has centered mainly on how participants present themselves and their national identities, as well as the balance in power dynamics brought by the nature of tandem learning, where the lack of a sole teacher or language expert democratizes the social dynamics field.

Telles has written about the concepts of national stereotypes and self-perceived identity within teletandem interactions (TELLES, 2015a) as well as the concept of transculturality, understood as the permeability of culture, rather than the traditional concept of cultures as separated and static entities (TELLES, 2012).

K. A. H. P. Ramos studies the belief system held by teletandem participants before a session, as beliefs influence how people learn a language, but also the belief system that emerges during a session in participants' discourse. She also recognizes discourse as " $a$ field for exercising power" (RAMOS, 2015). 
- | Deconstructing language learners' feelings of inferiority through teletandem

Helm explores the construction and reconstitution of identity whenever the participants in virtual exchanges interact. While the experience that she studies centers on technology-mediated interactions, they are not teletandem, but a broader kind of virtual experiences aimed towards foreign language learning such as online forums and blogs. Her aim is also the conception of self and the inequalities that arise in interactions between native speakers of a language with a large cultural capital, as Norton and Toohey define from Bourdieu's work as referring to "the knowledge, credentials, and modes of thought that characterize different classes and groups" (in NORTON; TOOHEY, 2011), and their interlocutors, who are second, third or even fourth language speakers. (HELM, 2018). Helm also explores the hegemonies of language and technology in telecollaboration where English is the language of the project and states that there is a fluid dialogic third space, one where power transits from one interlocutor to another (HELM; GUTH; FARRAH, 2012). This third space is significantly relevant, as it points to the space free of criticism, which is a characteristic of tandem learning (in person or through technology), and it is in that space that the shift in perceptions and attitudes towards the target language and its speakers can be attained.

Vassallo's work on power relations in teletandem is based on qualitative analysis of data from interviews of teletandem partnerships, focusing on the source, transit, and dynamics of power (VASSALLO, 2010). However, Vassallo's study focuses on the power dynamics of the actual language negotiation in a teletandem session, while this paper centers in how participants' preconceived notions, fixed even before they set foot in the computer lab, affects how they self-impose a social hierarchy based solely on their own beliefs.

One point that must be made is that the studies that most resemble the thesis of this paper focus on telecollaboration, tandem and teletandem projects with nonexpert parties who are not English language learners. For example, they were using English as a medium of collaboration (HELM, 2018) or were studying to become native or foreign language teachers (SALOMÃO, 2011; RAMOS, 2015). What is the relevance of this observation? On the one hand, that the perceptions and attitudes towards English of Mexican English learners participating in teletandem have implications beyond the reluctance or willingness to participate in the linguistic exchange, and thus, a more substantial potential to positively affect their language learning process; and on the other hand, that they do not possess the self and linguistic awareness that someone studying to become a language teacher does.

In order to explore the preconceived notions (or belief system, taking Ramos' term) of the self and the other, that Mexican English learners have, one must understand 
the context of Mexican students coming to an English language classroom. Despagne surveyed 300 Mexican university English learners in 2008, where 89.72\% stated that they knew that English was extremely important (DESPAGNE, 2010). Along the same line, in 2015 the British Council performed a study on the status of English in Mexico and, of the 1,000 Mexicans between the ages of 16 and 35 years old who participated, 58\% viewed English as a skill needed for greater employability, and $49 \%$ valued English as a pathway to a better job (BRITISH COUNCIL, 2015). There is no denying that Mexicans have extrinsic motivation for learning English, as 69\% out of 110 Mexican employers surveyed by the British Council said they felt English was an essential skill when hiring new staff. This extrinsic motivation is what Gardner and Lambert called instrumental motivation (motivation with a utilitarian objective), in contrast to integrative motivation (motivation to study a target language to successfully integrate within the community that speaks it) (GARDNER; LAMBERT, 1972).

The question that arises then is, whether Mexican students possess intrinsic motivation. Norton Peirce finds the distinction of instrumental and integrative motivation (GARDNER; LAMBERT, 1972) insufficient and, instead, uses the concept of investment, understood as a more complex concept that includes both the historical and social contexts and their resulting contradictory desires in the learner. From Norton Peirce's definition, investment takes into account that the learner studies another language striving to acquire both material resources as well as symbolic ones (NORTON PEIRCE, 1995). From this point of view then, Mexican English learners' investment is determined by both the clear extrinsic motivation, stated by both Despagne and the British Council studies, and by the complex perceptions and attitudes towards English and the United States by Mexican nationals. Despagne makes a distinction between perceptions and attitudes towards English in Mexico, with the first being what English means to Mexican learners, and the second, the specific behavior that results from the learners' perceptions (DESPAGNE, 2010). Thus, in order to understand better the baggage carried by the Mexican students who participated in these teletandem sessions, we need to understand what their perception of their target language is, their attitudes towards it and their investment in it, taking into account social and historical factors.

Pennycook states that English is "deeply interwoven with the discourses of colonialism" because of historical British imperialism and the more recent United States cultural and political one (PENNYCOOK, 1998). While Mexico was not a British colony, but a Spanish one, Mexican perception of the language is heavily affected by many sociocultural factors resulting from the country's colonial history and its relationship with the United States of America, the country that by its proximity and influence they find synonymous with the English language. Furthermore, Despagne states that: "[...] negative perceptions are 
- | Deconstructing language learners' feelings of inferiority through teletandem

predominant because learners automatically perceive English, consciously or unconsciously, as being related to economic, political and sociocultural problems between the US and Mexico" (DESPAGNE, 2010).

As mentioned in the introduction, the institutions collaborating with ITESO in teletandem are mainly from the United States, but a small number of sessions have occurred between ITESO and a Canadian university. Nevertheless, this has not had an impact in the attitudes and perceptions of ITESO's Mexican English learners, as even Canadian English is still seen through the same lens that relates the English language to the hegemonic power that the United States holds over Mexico.

It is also important to note that the negative attitude towards English is not just a result of the perception of the target language, but it also stems from Mexicans' complex feelings of national identity. Both S. Ramos (1934) and Paz (1950) talked about an unconscious feeling of inferiority among Mexicans, resultant from its colonial past and its external and self-imposed lower rank within Western civilizations. Moreover, Paz explains that Mexicans' never-ending search for identity defines this inferiority. Mexicans have even drawn from its colonial history when coining a term used to describe their attitudes towards what is national and what is foreign: malinchismo, from Malinche, the woman given to the conquistador, Hernán Cortés, as a mistress-slave-interpreter, who was a key figure in the Spanish colonization of Mexico. She is the symbol of betrayal to one's country and culture (COMISIÓN DE CONSULTAS DE LA ACADEMIA MEXICANA DE LA LENGUA, 2017). Malinchismo, in Mexico, describes the preference for what is foreign. The term has grown to describe not just this preference, but also, a degree of self-hatred, the assumption that whatever comes from another country, especially a first-world one, will always be better than what is Mexican. This has two connotations for Mexican students: on one hand, they expect the US students to be better than them, but also, it causes them to have a negative attitude towards learning English.

In 2011, Arias-Sais conducted a focus group comprised of students from the same university as the ones considered in this paper, and they expressed fear of speaking in English, of being judged, and of committing mistakes in the classroom (ARIAS-SAIS, 2014). This anxiety can be expected to be present in the teletandem session, especially when students are faced not only with fear of their shortcomings in the target language being witnessed by their teacher and peers, but also with them being observed by native or proficient speakers of English.

Another factor worth mentioning is Mexican students contact with the English language from an early age. Besides the strong penetration of English-language popular 
- | Deconstructing language learners' feelings of inferiority through teletandem

culture into Mexican culture, current Mexican students have been in a formal English language program since, at the very least, elementary school. Therefore, it is not surprising to think that those students reaching university without yet a B2 level of proficiency, display academic fatigue and lack of motivation. In the previously mentioned British Council study, $61 \%$ of participants stated that they had previously studied English. Of that $61 \%$, when asked about their motivation for studying the language, 51\% responded that it was mandatory during secondary school (BRITISH COUNCIL, 2015). This response highlights both the presence of English within the Mexican education system and, more telling, the perception of imposition. It is evident when contrasting the motivations given for learning English that followed in frequency "being mandatory in secondary school": "To improve my employment prospects" and "I needed to acquire English skills for university." Even more so, the fourth motivation is "It was mandatory during primary school." It is clear then that English is more widely perceived as a whim of Mexico's education policy-makers. (BRITISH COUNCIL, 2015).

The last factor to be explored is the role that English plays as a titulación provision. Many private universities in Mexico, including ITESO, have an English language requirement; it means that English can be a considerable obstacle in a student's social and economic mobility. When certifying proficiency in the language is a graduation condition, it can mean not graduating at all. Hence, the hostility towards learning English is understandable.

As a result of the factors that were stated above, Mexican English learners do not perceive their enrollment in English classes as an exercise of free-will, but as an imposition and, in many cases, a waste of time, effort and money. Consequently, a large number of students come into teletandem sessions with apprehension at best, or with a combatant attitude at worst.

Conversely, the circumstances bringing university-level Spanish learners to teletandem sessions is much different: with English being a lingua franca, they lack the urgency to learn a foreign language to ensure their socioeconomic mobility. When researching the graduation requirements of the universities and colleges that have collaborated in teletandem sessions with ITESO, most of them do include a foreign language one, but it goes from a minimum of one semester to a maximum of three for non-foreign language majors, of a freely chosen language, which could even include Latin in some cases. What becomes evident, when contrasting both participants, is that the (native or proficient) English speaker students possess a privilege of choice over their Mexican counterparts. 
- | Deconstructing language learners' feelings of inferiority through teletandem

For the analysis of the social interactions between the two participants in these teletandem sessions, this paper draws from Norton Peirce's work on the role of social identity and power relations within second language acquisition (NORTON PEIRCE, 1995); Pennycook's work on performativity and language (PENNYCOOK, 2004); and Telles work on teletandem and performativity (TELLES, 2015b).

Norton Peirce highlights the role of the social and historical background within the notions of identity, motivation, and investment in social interactions of non-native speaker groups, such as immigrant women in Canada (NORTON PEIRCE, 1995). She delves into concepts such as reluctance and the right to speak, which will be critical in the findings of this paper.

Pennycook explores beyond performativity within Austin's speech act theory (AUSTIN, 1962, 1971 in PENNYCOOK, 2004) and draws from Butler's work to examine the performative act of language in constituting identity (PENNYCOOK, 1998 \& 2004).

Telles adopts performativity theory to the teletandem experience to elucidate how the participants of the linguistic and cultural exchange build their national identity engaging in the linguistic performance of discussing their cultural differences (TELLES, 2015).

\section{Data Collection and Methodology}

Since Fall 2013, ITESO has asked students participating in teletandem sessions to fill out a post-session questionnaire, with the aim of evaluating the experience and gaining insight to improve the program in both infrastructure and pedagogy. This study uses the data gathered in the span of four years (from Spring semester, 2014 to Spring semester 2018). Out of 4,066 ITESO students who participated in the teletandem sessions, from its inception to Fall 2018, 2,101 students filled out the evaluation instrument. It is important to note that it was not designed with the intention of gathering data for a research study, and thus, while the data is significant, it is necessary to modify the instrument to collect new data to further this research.

The instrument used to collect the data included both quantitative-oriented items as well as qualitative-oriented ones: it included rating scale questions as well as open-ended ones. The quantitative data is used in its entirety, but only the qualitative data from all the teletandem sessions of one semester, Spring 2017, is used, this due to just the evaluation instrument of that semester having an extra question which inquired if participants' view of their interlocutors had changed after the session, and how. 
All the data was then analyzed using statistical analysis to correlate the shift observed by teachers and coordinators of the program in the attitudes of ITESO English learners towards both their linguistic partners and their target language.

\section{Findings and Discussion}

Before each session, participating Mexican English learners came into the computer lab displaying an evident reluctance, observed from their hesitation to sit down and put on their head phones to overt declarations of "You cannot make me do this." This observable behavior is congruent with what Krashen defined, as the affective filter comprised of the learner's motivation, self-confidence and anxiety state (KRASHEN, 1995).

In marked contrast, that affective filter appeared to have decreased at the end of the session, as it was evident, they were enthusiastic about repeating the experience. This change of attitude is demonstrated by the results of the post-session evaluation in the span of four years (SPRING, 2014 to SPRING 2018); out of 2,101 students who filled out the evaluation instrument, $97.48 \%$ declared that they wanted to repeat the experience, with the following spread of the desired number of sessions per term:

Willingness to repeat the experience

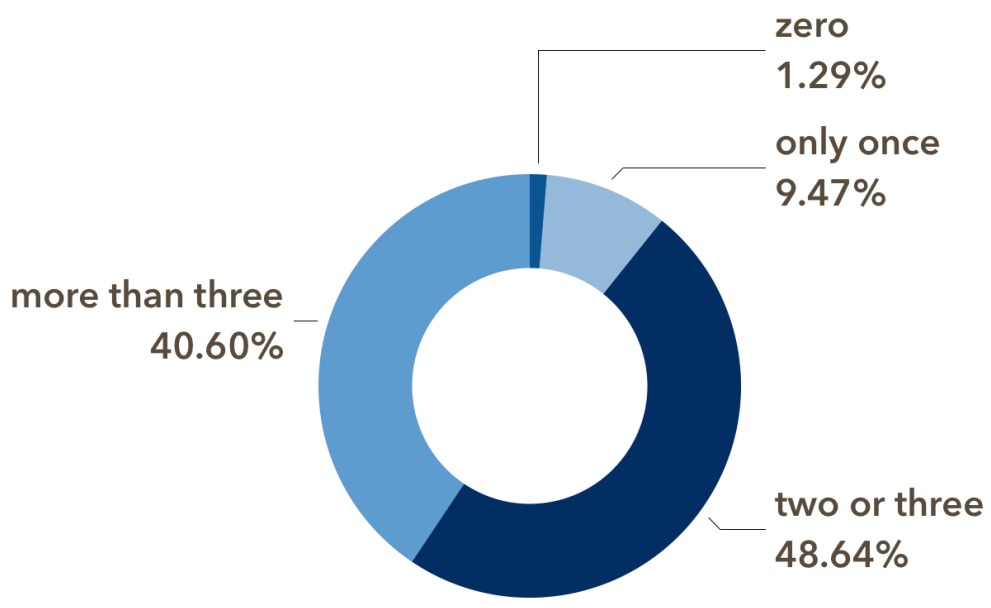

Distribution of responses of 2,101 participants

Remarkably $89.24 \%$ of participants wished to have two or more sessions per term. These figures attest to the willingness of Mexican participating students to repeat the experience. The increased willingness can be theorized to be intimately linked to the students' self-perceived agency within their target language command. For this article, agency is understood as A. Bandura's definition that "To be an agent is to intentionally make 
- | Deconstructing language learners' feelings of inferiority through teletandem

things happen by one's actions" (BANDURA, 2001). Therefore, this newly discovered agency could have a direct effect on student autonomy, as it changes the perception of the target language, from negative to positive. This shift stems from no longer perceiving learning English as an act of denying the importance of their self, but a part of a cultural exchange where their language and culture are highly valued. This is supported by mentions in the open-ended items in the evaluation instrument of finding their partners had a genuine interest in learning Spanish: "well, now I know that people from other countries want to learn my language and that they are open to help me, and for me to help them."

Norton Peirce talks about the reluctance to speak of immigrant English learner women in Canada and characterizes their decision to stay silent as a form of resistance in a power struggle where they are the weaker opponent (NORTON PEIRCE, 1995). The reluctance to participate in the teletandem session by the Mexican English learner can be interpreted as that form of resistance, as the only agency they can exercise (even if not a conscious decision). The contrast between studentbehavior before and after the sessions is evident from an anecdotal point of view, but it is also demonstrated by the results of the post-session questionnaire mentioned before. In this evaluation, they are asked about their level of confidence in their command of English both before and after the teletandem session by assigning it a score between 1-10, where 1 is the lowest level of confidence, and 10 is the highest. The results out of 2,101 students who responded are as follows: 


\section{Level of confidence in students' command of English before and after the session}
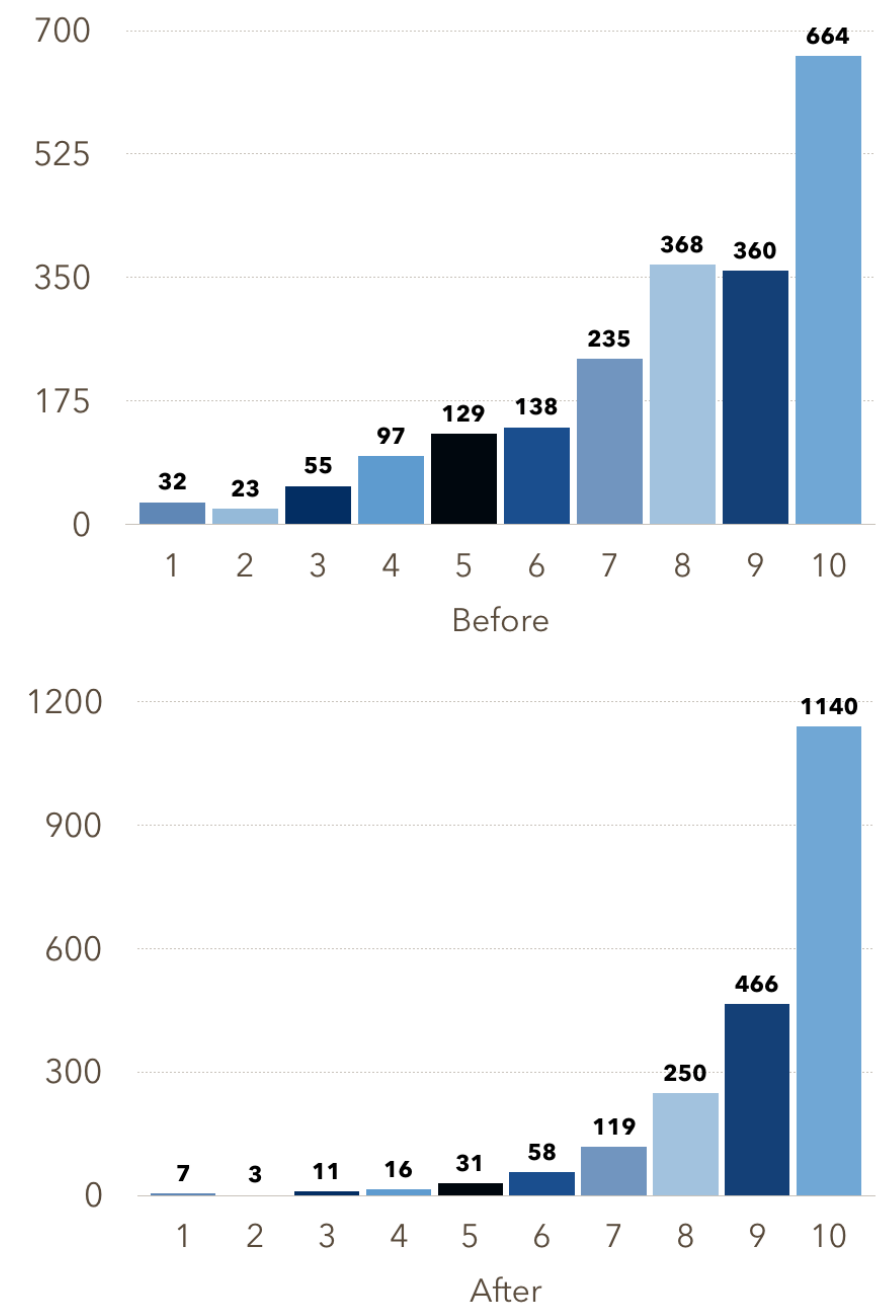

Distribution of responses of 2,101 participants of confidence before and after the session

These graphs illustrate that lower confidence decreased while higher confidence increased. More specifically, high confidence (score of 10) rose from $31.3 \%$ to $53.9 \%$, and strong confidence (score 9-10) from $48.3 \%$ to $76.4 \%$. In contrast, low confidence (score 1-4) decreased from $9.9 \%$ to $1.8 \%$.

What is the source of this surge in confidence in students' skills and command of the target language? The rise in confidence in the target language can be extrapolated as a boost in self-confidence. That, in addition to the $89.24 \%$ in willingness to participate in two or more teletandem sessions per term can be interpreted as what Norton Peirce calls claiming the right to speak (NORTON PEIRCE, 1995). If the refusal to speak was the only 
- | Deconstructing language learners' feelings of inferiority through teletandem

resource of agency target language learners could wield in a perceived unfavorable social interaction, then claiming the right to speak shows empowerment and an evening of the playing field in the social dynamics of language interaction.

It is essential to make a point here that the data does not demonstrate that the English learners participating in teletandem improved their linguistic abilities in their target language; a different study would have to include testing their skills before and after the sessions in order to gather data for such exploration. The presented data illustrates their perception of their confidence level before and after a session. While this information is not objective, it proves to be meaningful, since this study's concern is centered on the concept of identity and perception of self.

The teletandem session seems to change many of the students' preconceptions: for the first time, perhaps, the language they have studied for years is used in a real-life and practical context, and it is non-mediated by a teacher. After the session, most often than not, Mexican English learners report that their level in the target language tends to be higher than their partner's level of Spanish (due to English prevalence in their education and day-to-day life, while Spanish may be something more exotic in their counterpart's, something they may have chosen freely). This realization appears to increase the students' confidence in their language skills and even in themselves, and subsequently break longstanding negative preconceptions related to learning a foreign language. This is what students mentioned in the post-session questionnaire: "I thought that I would not be able to understand anything, but I did understand almost everything, I learned more" and "I thought it would be more difficult."

The post-session evaluation questionnaire of the sessions held in Spring 2017 had an additional question: "Did the session change your perspective about the culture/context of your conversation partner?" Out of 246 responses received that semester, 66.7\% reported a change in their perspective versus $33.3 \%$ who said no. In the follow-up question "How did the session change your perspective on the culture/context of your teletandem partner?" only 139 out of 246 participants answered it, and their answers were coded into 21 categories as listed in the table below. 


\section{How did the session change your perspective on the culture/context of your teletandem partner?}

\begin{tabular}{|c|c|c|}
\hline Answer & Incidence & Percentage \\
\hline I learned about cultural differences & 28 & $20.14 \%$ \\
\hline I learned new things about them and their country & 14 & $10.07 \%$ \\
\hline $\begin{array}{c}\text { We exchanged ideas about different topics, and we learned what } \\
\text { we each think about them }\end{array}$ & 11 & $7.91 \%$ \\
\hline We are not so different. We are alike in many ways & 10 & $7.19 \%$ \\
\hline I experienced something new, met new people and made friends & 9 & $6.47 \%$ \\
\hline I learned about their perspective/way of thinking & 7 & $5.04 \%$ \\
\hline We share the same struggles & 7 & $5.04 \%$ \\
\hline The experience changed preconceptions I had & 7 & $5.04 \%$ \\
\hline It was a way to learn English in a real context & 6 & $4.32 \%$ \\
\hline We are different people with very different perspectives and desires & 6 & $4.32 \%$ \\
\hline $\begin{array}{c}\text { It increased my confidence in myself / my command of the } \\
\text { language }\end{array}$ & 6 & $4.32 \%$ \\
\hline It was a reciprocal experience & 5 & $3.60 \%$ \\
\hline I learned about what they think about me/Mexicans & 5 & $3.60 \%$ \\
\hline There was no change in the way I think about "them" & 5 & $3.60 \%$ \\
\hline They are interested in my language and culture & 4 & $2.88 \%$ \\
\hline Opportunity to interact with people from different cultures & 2 & $1.44 \%$ \\
\hline They shared information about their identity with me & 2 & $1.44 \%$ \\
\hline $\begin{array}{l}\text { I learned they are not required to learn another language the way I } \\
\text { am required to learn English }\end{array}$ & 2 & $1.44 \%$ \\
\hline They did not criticize me & 1 & $0.72 \%$ \\
\hline I do not know & 1 & $0.72 \%$ \\
\hline I learned something new about technology & 1 & $0.72 \%$ \\
\hline Total & 139 & $100.00 \%$ \\
\hline
\end{tabular}


- | Deconstructing language learners' feelings of inferiority through teletandem

The results are then grouped by commonalities that are significant for identifying important aspects in which a paradigm shift can be elicited, such as identifying with the "other" by finding similarities; recognizing differences; and becoming more aware of reciprocity of the exchange, their individual and national identities and their learning process. The following chart shows those broader categories and their incidence:

\section{How did the session change your perspective on the culture/context of your teletandem} partner? (organized by commonalities)

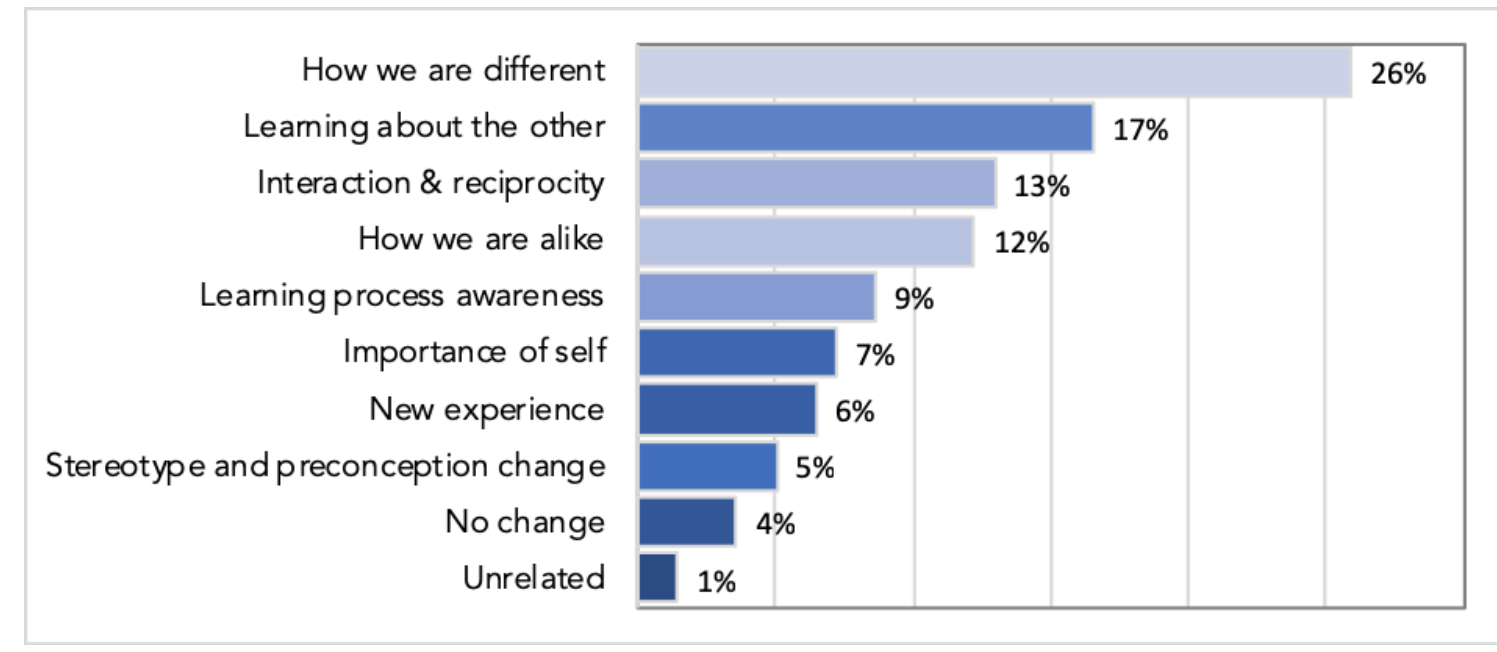

The post-session evaluation questionnaire is in itself an opportunity for teletandem participants to reflect on the experience they just had, as by responding, students are forced to become aware of the process they just experienced and its effects in their perception of their teletandem partners (as an individual as well as symbolically); their target language; and themselves.

Students responded alluding to their partners as individuals as well as referring to them as a collective "they." This is significant since both manners of address report a change in how they preconceived their partners would be, as individuals, but also that there was a shift in how the perceived the broader community of the speakers of their target language and of nationals of the country with whom they were interacting. 
Direct quotes from the teletandem participants to the question:

How did the session change your perspective on the culture/context

of your teletandem partner?

\begin{tabular}{|l|l|}
\hline 1 & $\begin{array}{l}\text { "You realize that they are in the same circumstances when learning another } \\
\text { language, that pronunciation, grammar, and all of that is not easy, you see all } \\
\text { that, and it is a good exercise for both by being able to practice both languages } \\
\text { and it is a very didactical way of doing it." }\end{array}$ \\
\hline 2 & $\begin{array}{l}\text { "I learned a lot about my partner, how her life is at university and her major, we } \\
\text { shared a lot! It was so much fun that it felt like } 15 \text { minutes." }\end{array}$ \\
\hline 3 & \begin{tabular}{l} 
"They are interested in learning Spanish [more] than what I thought." \\
"I thought that because she is from Miami she would party a lot, but she was \\
very calm and cool." \\
\hline 5
\end{tabular}$\quad$ "They are nice." \\
\hline
\end{tabular}

Translation of the original responses in Spanish

In his study of performativity and teletandem, Telles mentions the performative attribute of language, in a cultural and linguistic exchange, in constituting national identity. He warns of the risk of sessions becoming repetitive and remaining at a superficial level, because of participants' inclination for exploring their partner's cultural essentialisms, if the foreign language teacher does not properly mediate the implementation of teletandem (TELLES, 2015). Here lies the importance of preparation before the teletandem session and the reflection afterwards. ITESO participants prepare with their English language teachers in a class session before their linguistic exchange. There they share their thoughts on the experience on which they are about to embark and work on a questionnaire that they can use as a guide in case they run out of things to say. This questionnaire is critical for two reasons: a) it is a safety net that assuages their feelings of anxiety and b) it is not a questionnaire dictated by their teacher, but something prepared by themselves, which gives them a sense of agency, just prior to a daunting activity where they fear they will be stripped of power. After the teletandem experience, they also hold a reflective roundtable, where they discuss the experience in the subsequent class session.

Pennycook and Norton Peirce's work on identity and language both highlight how identity is not static but in flux: "[...] when language learners speak, they are not only exchanging information with target language speakers but they are constantly 
- | Deconstructing language learners' feelings of inferiority through teletandem

organizing and reorganizing a sense of who they are and how they relate to the social world." (NORTON PEIRCE, 1995, p. 18) and "[Performativity] provides a way of thinking about relationships between language and identity that emphasizes the productive force of language in constituting identity rather than identity being a pregiven construct that is reflected in language use" (PENNYCOOK, 2004, p. 13).

Both authors state how identity is not something already defined and unchangeable: Mexican students coming to the teletandem session perceive their identity, and that of their session partner, as something written in stone that relegates them to an inferior place in the social interaction. However, what happens after the session is, as Norton Peirce and Pennycook state, that their identity is something that is constantly being reorganized through language. Making students aware of this will significantly enhance their motivation and investment in learning English and, it will encourage them to become autonomous learners.

In her book on the topic of new identities arising from telecollaboration projects, Helm notes the critical role that identity has in linguistic interaction: "shifting identity positionings influence interaction patterns as they can alter the power dynamics and have impact on participants' investment in the dialogue process" (HELM, 2018, p. 14).

There is no question then on the influential role teletandem has in heightening motivation and confidence in the target language, as well as impacting participants' sense of self.

\section{Conclusion}

As demonstrated with the quantitative data gathered by the post-session evaluation related to the willingness to repeat the experience, students express a desire to repeat the experience. This increased willingness clearly demonstrates that students are motivated to participate again in an activity in which they had been reluctant to engage initially. This motivation is important because what they achieved with the session concerning their language skills is derived from their work. They are, as Norton Peirce proposes, claiming the right to speak (NORTON PEIRCE, 1995).

Beyond the rise in motivation, the data also demonstrated a shift in participants perceived skills in the target language. The evaluation instrument was not concerned with revealing the linguistic growth of the English learners participating in teletandem, but having them rate their confidence in the skills they already possessed in the language, 
taking into account what the session (and the reflection the evaluation elicited) did to their perception of selves. The results clearly showed a significant increment in high confidence and a reduction in low confidence.

The qualitative data, while significantly smaller in comparison to the quantitative dataset, should not be dismissed since it provides relevant information about the students' awareness of the change in perception they experienced through the teletandem session. Reviewing the categories used to code the responses, participants display linguistic and learning awareness, as well as elevated self-esteem and cultural aperture; all meaningful to vanquish the self-imposed limitations and feelings of inferiority that make Mexican English learners be predisposed to a power struggle where they expect to be the lesser party.

All stated above pinpoint to the potential of teletandem for being a gateway for participants to become autonomous learners. They discover that they can learn because of their actions and after a session, many of them continue to seek similar experiences on their own. One can only hope that by promoting teletandem opportunities and guiding students to procure them for themselves, they will work towards becoming highly invested and motivated autonomous learners.

There are limitations to what the collected data of this study, as extensive as it may be, can achieve, given that the instrument for collection was not designed for exploring the thesis of this paper, but for a more practical one: as formative assessment that would then be used to improve the program (a significant number of the items in the evaluation instrument dealt with quality of the technological mediation and ways to make logistics and processes for the procurement of the sessions more efficient). Thus, it is highly recommended that further research is done, with a new evaluation instrument that is better suited to further the thesis of this article, and with other data collection instruments, such as focus groups to conduct interviews with participating students and follow up on more long-lasting effects of teletandem sessions in ITESO's English learners language studies and real-context use of the target language. 
- | Deconstructing language learners' feelings of inferiority through teletandem

\section{References}

ARIAS-SAIS, G. Addressing Attitudes of Anxiety and Inferiority among English Language Learners in Mexico. Repositorio Institucional del ITESO, November 2014. Available in: http://hdl.handle.net/11117/2434. Access: April 19, 2016.

BANDURA, A. Social Cognitive Theory: An Agentic Perspective. Annual Review of Psychology, v. 52, p. 1-26, 2001.

BRINCKWIRTH, A. Implementation and outcomes of an online English-Portuguese tandem language exchange program delivered jointly across a US-Brazilian university partnership: a case study, (Ph.D. Dissertation). Virginia Commonwealth University, 2012.

BRITISH COUNCIL. English in Mexico: An Examination of Policy, Perceptions and Influencing Factors. British Council, 2015. Available in: https://ei.britishcouncil.org/sites/ default/files/latin-america-research/English\%20in\%20Mexico.pdf. Access: November $16,2017$.

CAPELLINI, M. Roles and scaffolding in teletandem interactions: a study of the relations between the sociocultural and the language learning dimensions in a French-Chinese teletandem. Innovation in Language Learning and Teaching, v. 10, n. 1, p. 6-20, 2016.

CARTWRIGHT, R. Some Remarks on Essentialism. The Journal of Philosophy, v. 65, n. 20, p. 615-626, 1968.

COMISIÓN DE CONSULTAS DE LA ACADEMIA MEXICANA DE LA LENGUA. Malinchismoy malinchista. Academia Mexicana de la Lengua, 2017. Available in: https://www.academia. org.mx/academicos-2017/item/malinchismo-y-malinchista. Access: March 4, 2018.

CONSOLO, D. A.; FURTOSO, V. B. Assessing oral proficiency in computer-assisted foreign language learning: A study in the context of teletandem interactions. DELTA: Documentação de Estudos em Lingüística Teórica e Aplicada, v. 31, n. 3, p. 665-689, 2015.

DESPAGNE, C. The Difficulties of Learning English: Perceptions and Attitudes in Mexico. Canadian and International Education / Education canadienne et internationale, v. 39, n. 2, p. 54-74, 2010. 
GARDNER, R. C.; LAMBERT, W. C. Attitudes and Motivation in Second Language Learning. Rowley, Massachusetts: Newbury House, 1972.

HELM, F. Emerging identities in virtual exchange. Voillans: Research Publishing, 2018.

HELM, F.; GUTH, S.; FARRAH, M. Promoting dialogue or hegemonic practice? Power issues in telecollaboration. Language Learning \& Technology, v. 16, n. 2, p. 103-127, 2012.

KRASHEN, S. D. Principles and Practice in Second Language Acquisition. New York: Phoenix ELT, 1995.

MAGAZINER, J.; MONROY, C. Education in Mexico. World Education News + Reviews, 2016. Available in: https://wenr.wes.org/2016/08/education-in-mexico. Access: March 4, 2018.

NORTON, B.; TOOHEY, K. Identity, language learning, and social change Language teaching, v. 44, n. 4, p. 412-446, 2011.

NORTON PEIRCE, B. Social Identity, Investment, and Language Learning. TESOL Quarterly, v. 29, n. 1, p. 9-31, 1995.

PAZ, O. El laberinto de la soledad. México, D.F.: Ediciones Cuadernos Americanos, 1950.

PENNYCOOK, A. English and the Discourses of Colonialism. New York: Routledge, 1998.

PENNYCOOK, A. Performativity and Language Studies. Critical Inquiry in language studies: An international journal, v. 1, n. 1, p. 1-9, 2004.

RAMOS, K. A. H. P. Interactants' beliefs in teletandem: Implications for the teaching of Portuguese as a foreign language. DELTA: Documentação de Estudos em Lingüística Teórica e Aplicada, v. 31, n. 3, p. 691-709, 2015.

RAMOS, S. El perfil del hombre y la cultura en México. México, D.F.: Planeta Mexicana.

SALOMÃO, A. C. B. Collaborative language learning in teletandem: A resource for preservice teacher education. Profile Issues in Teachers Professional Development, v. 13, n. 1, p. 139-156, 2011. 
- | Deconstructing language learners' feelings of inferiority through teletandem

SECRETARÍA DE EDUCACIÓN PÚBLICA. Programa Nacional de Inglés en Educación Básica, 2009. Available in: http://pnieb.net/inicio.html. Access: March 1, 2018.

SUNY COIL CENTER. About COIL, 2013. Available in: http://coil.suny.edu/page/aboutcoil-0. Access: November 28, 2018.

TELETANDEM BRASIL: FOREIGN LANGUAGES FOR ALL. UNESP - Universidade Estadual Paulista, 2015. Available in: http://www.teletandembrasil.org/. Access: November 28, 2018.

TELLES, J. A. Teletandem: Transculturality and identity in webcam interactions in foreign languages. Conference Proceedings, International Conference ICT for Language Learning, p. 20-21, 2012.

TELLES, J. A. Learning foreign languages in teletandem: Resources and strategies. DELTA: Documentação de Estudos em Lingüística Teórica e Aplicada, v. 3, n. 3, p. 603-632, 2015a.

TELLES, J. A. Teletandem and performativity. Revista Brasileira de Linguística Aplicada, v. 15, n. 1, p. 1-30, 2015 b.

VASSALLO, M. L. Relações de poder em parcerias de teletandem. Repositório Institucional UNESP, 2010.

WORLD HERITAGE ENCYCLOPEDIA. Tandem Language Learning, n/d. Available in: http://www.worldheritage.org/articles/Tandem_language_learning. Access: March 1, 2018.

COMO CITAR ESTE ARTIGO: ZULAICA-GÓMEZ, Paula A. Deconstructing language learners' feelings of inferiority through teletandem. Revista do GEL, v. 15, n. 3, p. 302323, 2018. Disponível em: https://revistadogel.gel.org.br/

DOI: http://dx.doi.org/10.21165/gel.v15i3.2394

Submetido em: 09/11/2018 | Aceito em: 28/12/2018. 